\title{
SPATIAL VARIABILITY OF LEAF WETNESS DURATION IN A 'NIAGARA ROSADA' VINEYARD
}

\author{
JORGE LULU ${ }^{1}$, PAUlO C. SENTELHAS ${ }^{2}$, MÁRIO J. PEDRO JÚNIOR ${ }^{3}$, \\ JOSÉ R. M. PEZZOPANE ${ }^{4}$, GABRIEL C. BLAIN ${ }^{5}$
}

\begin{abstract}
Despite considerable efforts to develop accurate electronic sensors to measure leaf wetness duration (LWD), little attention has been given to studies about how is LWD variability in different positions of the crop canopy. In order to evaluate the influence of 'Niagara Rosada' (Vitis labrusca) grapevine structure on the spatial variability of LWD, the objective of this study was to determine the canopy position of the 'Niagara Rosada' table grape with longer LWD and its correlation with measured standard LWD over turfgrass. LWD was measured in four different canopy positions of the vineyard (sensors deployed at $45^{\circ}$ with the horizontal): at the top of the plants, with sensors facing southwest and northeast (Top-SW and Top-NE), and at the grape bunches height, with sensors facing southwest and northeast (Bottom-SW and Bottom-NE). No significant difference was observed between the top $(1.6 \mathrm{~m})$ and the bottom $(1.0 \mathrm{~m})$ of the canopy and also between the southwest and northeast face of the plants. The relationship between standard LWD over turfgrass and crop LWD in different positions of the grape canopy showed a define correlation, with $\mathrm{R}^{2}$ ranging from 0.86 to 0.89 for all period, from 0.72 to 0.77 for days without rain, and from 0.89 to 0.91 for days with rain.
\end{abstract}

KEYWORDS: dew, rain, flat plate wetness sensor.

\section{VARIABILIDADE ESPACIAL DA DURAÇÃO DO PERÍODO DE MOLHAMENTO EM VINHEDO DE 'NIAGARA ROSADA'}

RESUMO: Apesar dos esforços consideráveis para se desenvolverem sensores eletrônicos acurados para medir a duração do período de molhamento (DPM), pouca atenção tem sido dada às pesquisas sobre a variabilidade da DPM no interior do dossel das culturas. A fim de avaliar a influência da estrutura da cobertura vegetal da videira 'Niagara Rosada' (Vitis labrusca) na variabilidade espacial da DPM, o objetivo do presente estudo foi determinar a posição da videira com a maior DPM e sua relação com a DPM medida em condição-padrão (no gramado). Para tanto, a DPM foi medida em quatro diferentes posições da planta, com os sensores inclinados em $45^{\circ}$ em relação à horizontal: topo da planta com a face superior do sensor voltada para sudoeste e nordeste (Topo-SW e TopoNE) e altura dos cachos de uva com a face superior do sensor voltada para sudoeste e nordeste (Dossel-SW e Dossel-NE). Não houve diferença significativa da DPM tanto entre a parte mais alta $(1,6 \mathrm{~m})$ e a parte mais baixa $(1,0 \mathrm{~m})$ da planta, como entre as faces sudoeste e nordeste das plantas. As relações entre os dados de DPM sobre o gramado e nas diversas posições da cobertura vegetal, obtidas por meio de regressão linear simples, apresentaram correlações bem definidas, com valores de $\mathrm{R}^{2}$ variando de 0,86 a 0,89 para todo o período, de 0,72 a 0,77 para os dias sem chuva e de 0,89 a 0,91 para os dias com chuva.

PALAVRAS-CHAVE: orvalho, chuva, sensor de molhamento de placa plana.

\footnotetext{
${ }^{1} \mathrm{PhD}$ candidate, Department of Exact Sciences, Esalq/USP/Piracicaba - SP - Brazil, Phone: (55) (19) 3276-4707 / 9157-6689, j_lulu@yahoo.com

${ }^{2}$ Associate Professor, Department of Exact Sciences, Esalq / USP / Piracicaba - SP - Brazil.

${ }^{3}$ Researcher, Center of Research and Development of Ecophysiology and Biophysics, IAC, Campinas - SP - Brazil.

${ }^{4}$ Assistent Professor, Academical Center of North of Espírito Santo, UFES, São Mateus - ES - Brazil.

${ }^{5}$ Researcher, Center of Research and Development of Ecophysiology and Biophysics, IAC, Campinas - SP - Brazil. Recebido pelo Conselho Editorial em: 28-2-2007
}

Aprovado pelo Conselho Editorial em: 6-2-2008 


\section{INTRODUCTION}

Wetness presence on the surface of the plants, caused by dew, rain or irrigation, provides the water requested by the patogens for the germination process and infection of the leaf tissue (GUYOT et al., 2005). Dew is defined as the water condensed on the surface when the air temperature reaches the dew point due to the intense cooling for long wave radiative loss (PEREIRA et al., 2002). The dew point (Td) of a sample of air with a given vapor pressure (e) is the temperature to which it must be cooled to become saturated (MONTEITH, 1961). Dew happens in natural surfaces, especially in plant canopies, where it can be originated from two different processes: the "dew precipitation", when the condensation of vapor is originated from the immediately superior layer, adjacent to the surface, and the "dew distillation", when the condensation of vapor is originated from the soil or another leaf, being both function of the vapor pressure gradient (BURRAGE, 1972; SHARMA, 1976). However, according to RAMAN et al. (1973), the condensation in the inferior leaf face is, usually, insignificant when compared with the process that promotes the condensation in the superior face of the leaves.

BURRAGE (1972) and VAN DER WAL (1978) pointed out that the period during water (dew and/or rain) is present on the plants, named leaf wetness duration (LWD), is much more important than the total water amount stored by the leaves, especially regarding diseases development. Therefore, the measurement or estimation of this variable is of extreme importance for studies about plant disease epidemiology. Even when the measurements are available, the spatial variability of leaf wetness duration can limit the use of these measurements in places with distance longer than 30 $\mathrm{km}$ of a weather station (RAO et al., 1998; KIM et al., 2005). Despite considerable efforts to develop accurate electronic sensors to measure the LWD, little attention has been given to the research about how is LWD variability in different positions of the crop canopies (SENTELHAS et al., 2005).

Up to now, LWD measurement has not been done as part of a standard observation program by the meteorological agencies (DALLA MARTA et al., 2005). It happens mainly due to lack of a standard sensor project and a protocol to use this sensor (SABATINI et al., 2004).

The flat plate wetness sensors, when correctly treated with painting (white latex paint) and heating can provide measurements of high precision and accuracy (SENTELHAS et al., 2004). However, the position (height and angle) of the LWD sensor has effect on the measurements. According to the authors cited above, in higher positions LWD measurements are shorter than at 30 $\mathrm{cm}$, and in smaller angles, longer than in larger one. As a standard for LWD measurements over turfgrass in a weather station, the position of the sensor at $30 \mathrm{~cm}$ height and with an angle ranging from 30 to $45^{\circ}$ to horizontal showed to be the most suitable (SENTELHAS et al., 2004). According to these authors, when LWD data of a reference sensor (at $30 \mathrm{~cm}$ over turfgrass and deployed at a $30^{\circ}$ angle) were correlated with measurements of LWD on the top of the crop canopies, good relationships were obtained, which suggest that the crop LWD can be estimated sufficiently well for several operational purposes from LWD measurements obtained in a weather station.

In order to evaluate the influence of 'Niagara Rosada' grapevine structure on the spatial variability of LWD, the objective of the present study was to determine the canopy position with the longest LWD and the relationship between measured LWD in four different positions of the crop canopy and LWD measured in a standard position, at $30 \mathrm{~cm}$ over turfgrass in a standard weather station.

\section{MATERIAL AND METHODS}

The field trial was carried out in the Advanced Center of Technological Research of Agrobusiness of Fruits (AGRONOMIC INSTITUTE - IAC), in Jundiaí, São Paulo State (SP), Brazil (Lat.: 23 $12^{\prime} \mathrm{S}$; Long.: 46 53' W; Alt.: $715 \mathrm{~m}$ ), from 11 November 2005 to 05 March 2006 (115 days). The LWD was measured in a 'Niagara Rosada' vineyard ( $2 \times 1 \mathrm{~m})$ cultivated in a hedgerow training system (Figure 1) and in a turfgrass area by an automatic weather station, located 
at $200 \mathrm{~m}$ from the vineyard. It was used electronic wetness sensors (painted flat plate, printed circuit) (Campbell Scientific, model 237), mounted in sections of PVC tubes, with an angle of $45^{\circ}$ to horizontal (Figure 2a), connected in a datalogger (Campbell Scientific, model CR 23X) (Figure 2b).

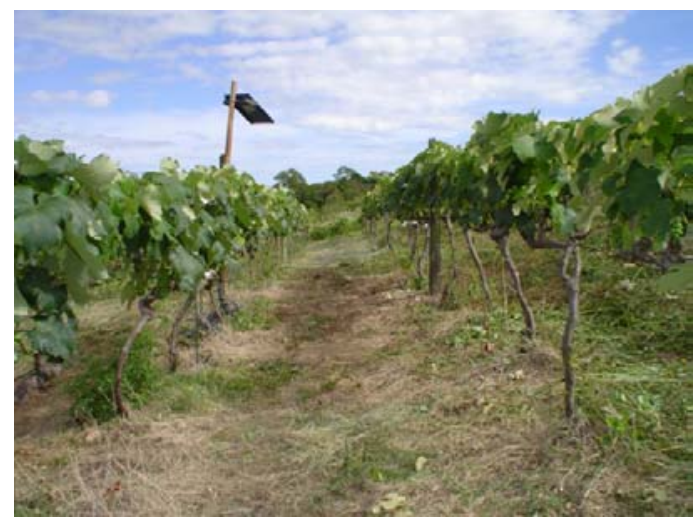

FIGURE 1. General view of the vineyard experimental area, in Jundiaí, SP, Brazil.
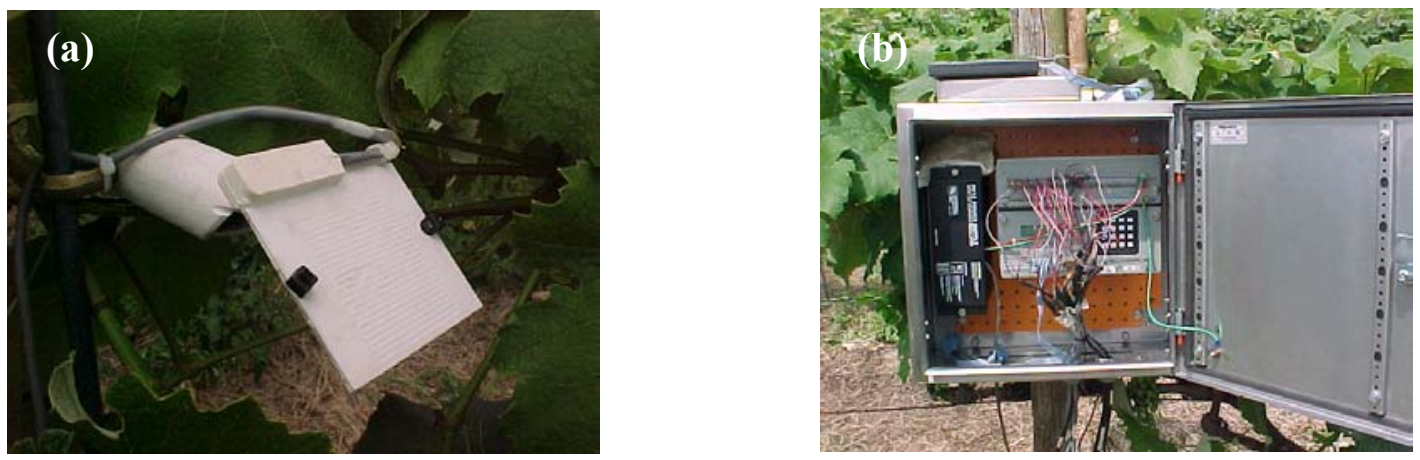

FIGURE 2. Detail of a flat plate wetness sensor (a) and the datalogger (b) inside the vineyard, in Jundiaí, SP, Brazil.

Wetness sensors were used to study the spatial variability of LWD in the grapevine, verifying the difference among measured LWD in four different positions of the crop canopy (with 3 replications) and LWD measured in a standard position, at $30 \mathrm{~cm}$ over turfgrass in a standard weather station. At the vineyard, LWD sensors were installed in two different heights of the canopy: at the top $(1.6 \mathrm{~m})$ and at the grape bunches height $(1.0 \mathrm{~m})$. The wetness sensors inside the vineyard and at the standard weather station are shown in the Figure 3.
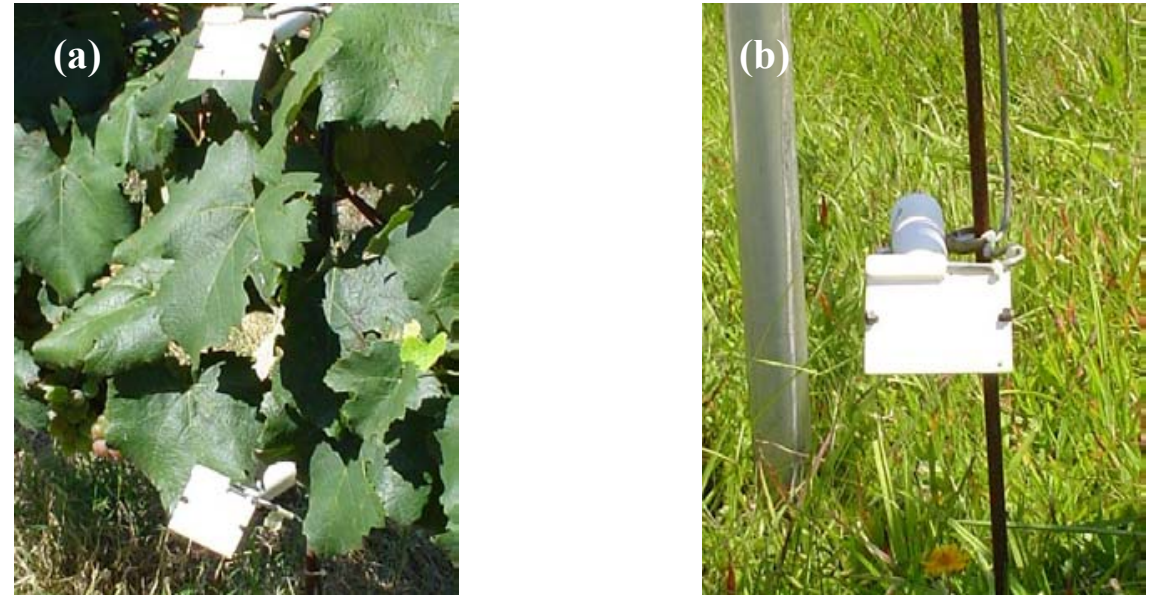

FIGURE 3. Wetness sensors inside the vineyard (a) and at the standard weather station (b), in Jundiaí - SP, Brazil. 
The four different positions of the sensors in the grapevine were: plant top and sensor facing northeast (Top-NE), grape bunches height and sensor facing northeast (Bottom-NE), plant top and sensor facing southwest (Top-SW), and grape bunches height with sensor facing southwest (Bottom-SW) (Figure 4).
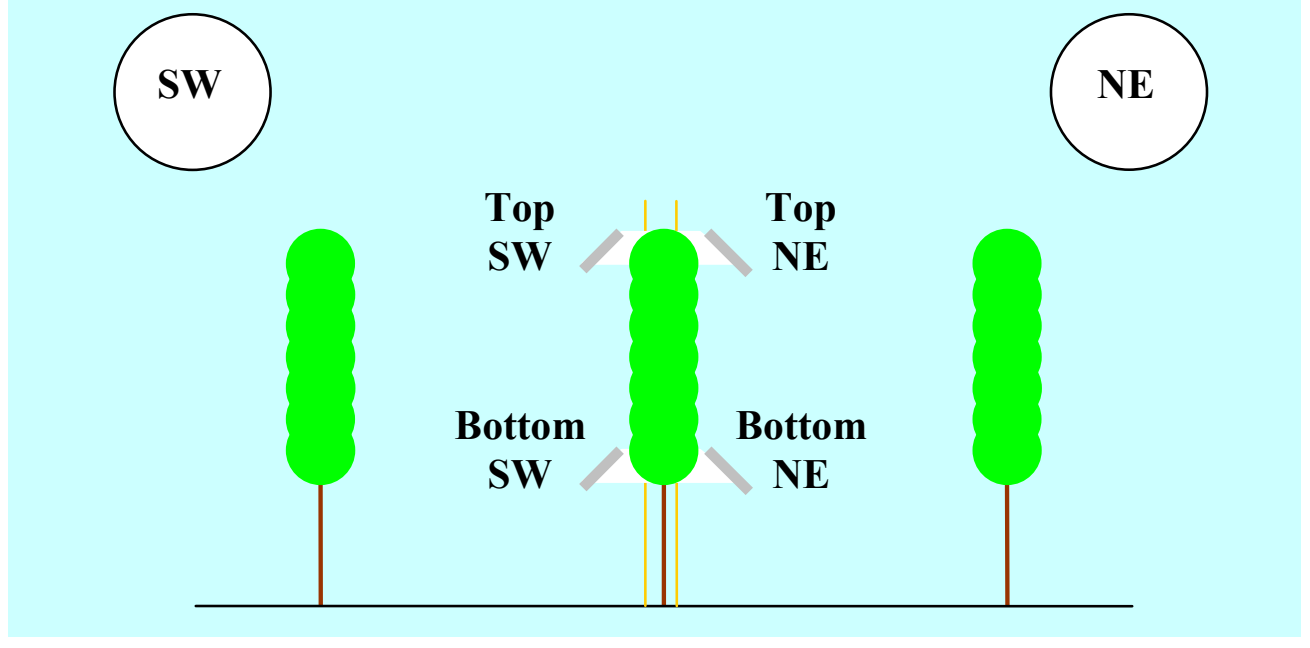

FIGURE 4. Schematic of wetness sensors positions in the grapevine (Top-NE, Bottom-NE, TopSW and Bottom-SW).

Average daily crop LWD data, considering the total period and also spliting the days with and without rainfall, were analyzed by the " $t$ " test at $5 \%$ of probability level. The relationship between LWD over turfgrass and crop LWD, obtained in the four different positions of the crop canopy, were determined by regression analisys. The mean difference (MD) and the mean absolute difference (MAD) between them were also calculated for each position of the canopy, considering all available days and just days with and without rainfall.

\section{RESULTS AND DISCUSSION}

Table 1 shows the average values of LWD in the four different positions of the crop canopy and also at the standard position over turfgrass, considering all days and only days with and without rainfall, as well as the statistical analysis. The values of MD and MAD between LWD over turfgrass and LWD at the vineyard, and between the different positions of the plant are presented in Table 2.

TABLE 1. Average daily leaf wetness duration (LWD) (h) in the four different grape canopy positions (Top-NE, Bottom-NE, Top-SW and Bottom-SW) and also in the standard position over turfgrass (Turfgrass-S), considering all days and days with and without rainfall, from 11 November 2005 to 05 March 2006, and the results of the statistical analysis, in Jundiaí, SP, Brazil.

\begin{tabular}{lccccc}
\hline & Top-NE & Bottom-NE & Top-SW & Bottom-SW & Turfgrass-S \\
\hline $\begin{array}{l}\text { Average LWD } \\
\text { (all days) }\end{array}$ & $11.2 \mathrm{ab}$ & $10.7 \mathrm{~b}$ & $11.9 \mathrm{ab}$ & $10.8 \mathrm{~b}$ & $12.3 \mathrm{a}$ \\
$\begin{array}{l}\text { Average LWD } \\
\text { (days with rain only) }\end{array}$ & $14.7 \mathrm{a}$ & $14.2 \mathrm{a}$ & $15.1 \mathrm{a}$ & $14.5 \mathrm{a}$ & $15.4 \mathrm{a}$ \\
$\begin{array}{l}\text { Average LWD } \\
\text { (days without rain only) }\end{array}$ & $8.0 \mathrm{~b}$ & $7.5 \mathrm{~b}$ & $9.0 \mathrm{ab}$ & $7.5 \mathrm{~b}$ & $9.5 \mathrm{a}$ \\
\hline
\end{tabular}

Averages in the same line followed by the same letter are not significantly different by the "t" test at $5 \%$ of probability level. 
TABLE 2. Leaf wetness duration (LWD) mean difference (MD) and mean absolute difference (MAD), in hours, among the four different positions of the grape canopy (Top-NE, Bottom-NE, Top-SW and Bottom-SW) and among them and the standard position over turfgrass (Turfgrass-S), considering all days and days with and without rainfall, from 11 November 2005 to 05 March 2006, in Jundiaí, SP, Brazil.

\begin{tabular}{lrrrrrr}
\hline & \multicolumn{2}{c}{ All days } & \multicolumn{2}{c}{ Days with rainfall } & \multicolumn{2}{c}{ Days without rainfall } \\
\cline { 2 - 6 } & MD & MAD & MD & MAD & MD & MAD \\
\hline Top-SW / Top-NE & 0.67 & 0.76 & 0.38 & 0.50 & 0.96 & 1.03 \\
Top-SW / Bottom-SW & 1.07 & 1.15 & 0.66 & 0.81 & 1.49 & 1.49 \\
Top-SW / Bottom-NE & 1.20 & 1.26 & 0.90 & 0.94 & 1.53 & 1.58 \\
Top-SW / Turfgrass-S & -0.42 & 1.11 & -0.22 & 0.77 & -0.45 & 1.35 \\
Top-NE / Bottom-SW & 0.40 & 0.74 & 0.28 & 0.71 & 0.54 & 0.77 \\
Top-NE / Bottom-NE & 0.53 & 0.70 & 0.52 & 0.66 & 0.57 & 0.74 \\
Top-NE / Turfgrass-S & -1.09 & 1.31 & 0.60 & 0.81 & -1.41 & 1.69 \\
Bottom-SW / Bottom-NE & 0.13 & 0.61 & 0.24 & 0.62 & 0.03 & 0.64 \\
Bottom-SW / Turfgrass-S & -1.49 & 1.54 & -0.88 & 1.01 & -1.95 & 1.96 \\
Bottom-NE / Turfgrass-S & -1.62 & 1.70 & -1.13 & 1.27 & -1.98 & 2.04 \\
\hline
\end{tabular}

Inside the vineyard there was no significant difference between the top and the bunches height, as well as between the southwest and northeast faces of the crop canopy (Table 1). However, LWD tended to be longer at the top of the canopy at the southwest face. This probably happened because the wetness in this part of the plant begun earlier, since it was the most exposed part of the canopy to the sky, obtaining a more negative net radiation than the other positions of the grapevine canopy. Besides, the leaves facing southwest, at this latitude, received less solar radiation in southern hemisphere, being the less sunny and with smaller temperatures than the other face. Therefore, this face of the canopy uses to have wetness onset earlier and dry-off later than northeast face.

Considering all available days (Table 1), LWD inside the vineyard was longer at the Top-SW position and shorter at the Bottom-NE position, with the highest MD and MAD values between them (Table 2). WITTICH (1995), for an apple tree, also observed a higher LWD at the top of the canopy. However, in the present experiment, the LWD did not differ significantly between the 4 different positions of the plant (Table 1). The same was observed by SENTELHAS et al. (2005) for the 'Niagara Rosada' grapevine, evaluating just two positions: top of the canopy and grape bunches height. However, the standard LWD over turfgrass differed significantly from LWD at Bottom-NE and Bottom-SW positions of the canopy (Table 1). The MD and MAD between Bottom-NE and Turfgrass-S positions were -1.62 and $1.70 \mathrm{~h}$, respectively, while between Bottom-SW and Turfgrass-S positions were -1.49 and $1.54 \mathrm{~h}$ respectively (Table 2). DALLA MARTA et al. (2004) also found differences around that for a vineyard in Italy.

The spatial variability of LWD among the different positions of the grapevine canopy also can be seen at Figure 5, where average values are presented for each replication.

A small difference were observed in the pattern of LWD variability among the three plants (Figure 5), showing that the averages were representative for the spatial variability analysis. The average LWD of the three plants, at the four different positions of the grapevine and also at the standard condition over turfgrass, for all days and days without and with rainfall are shown in Figure 6. 


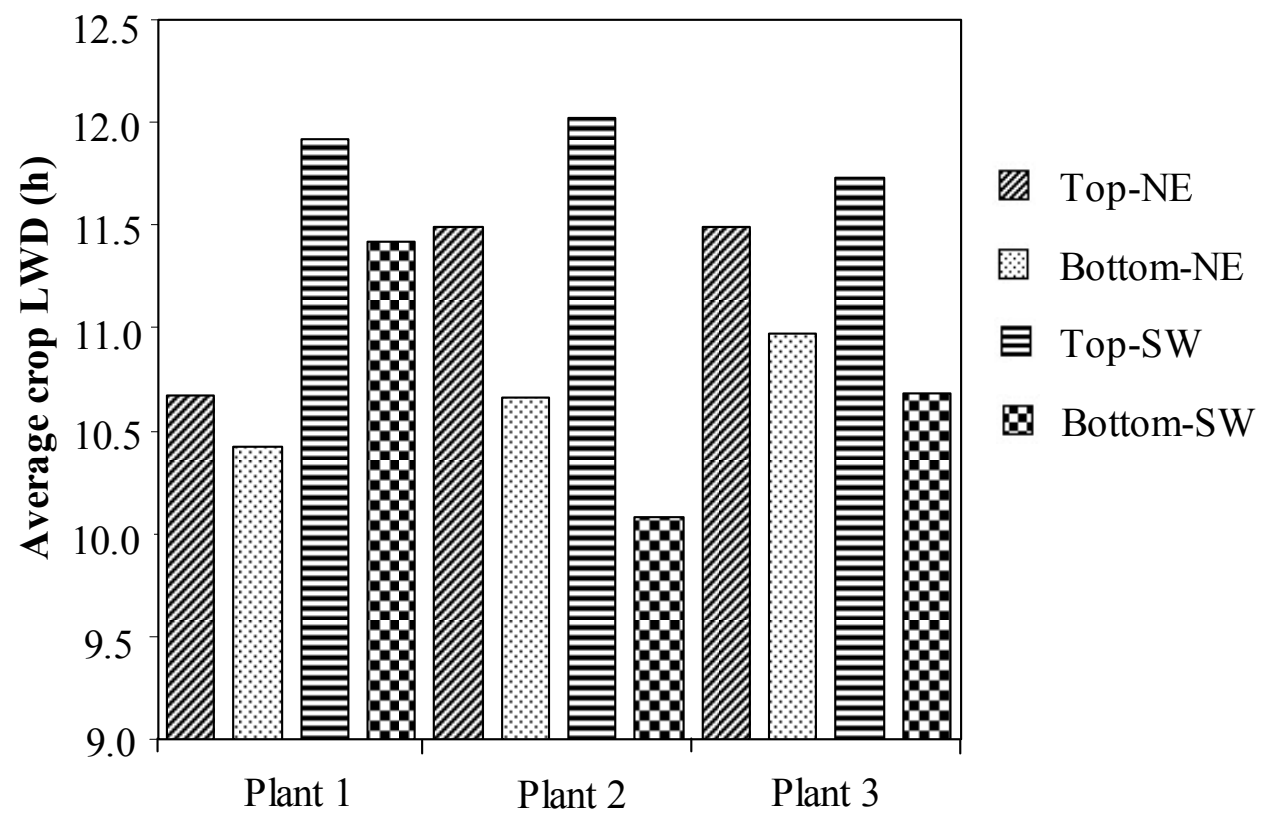

Position

FIGURE 5. Average leaf wetness duration (LWD) at the grapevine canopy for each replication (Plants 1, 2 and 3), at different positions: Top-NE, Bottom-NE, Top-SW and Bottom-SW.

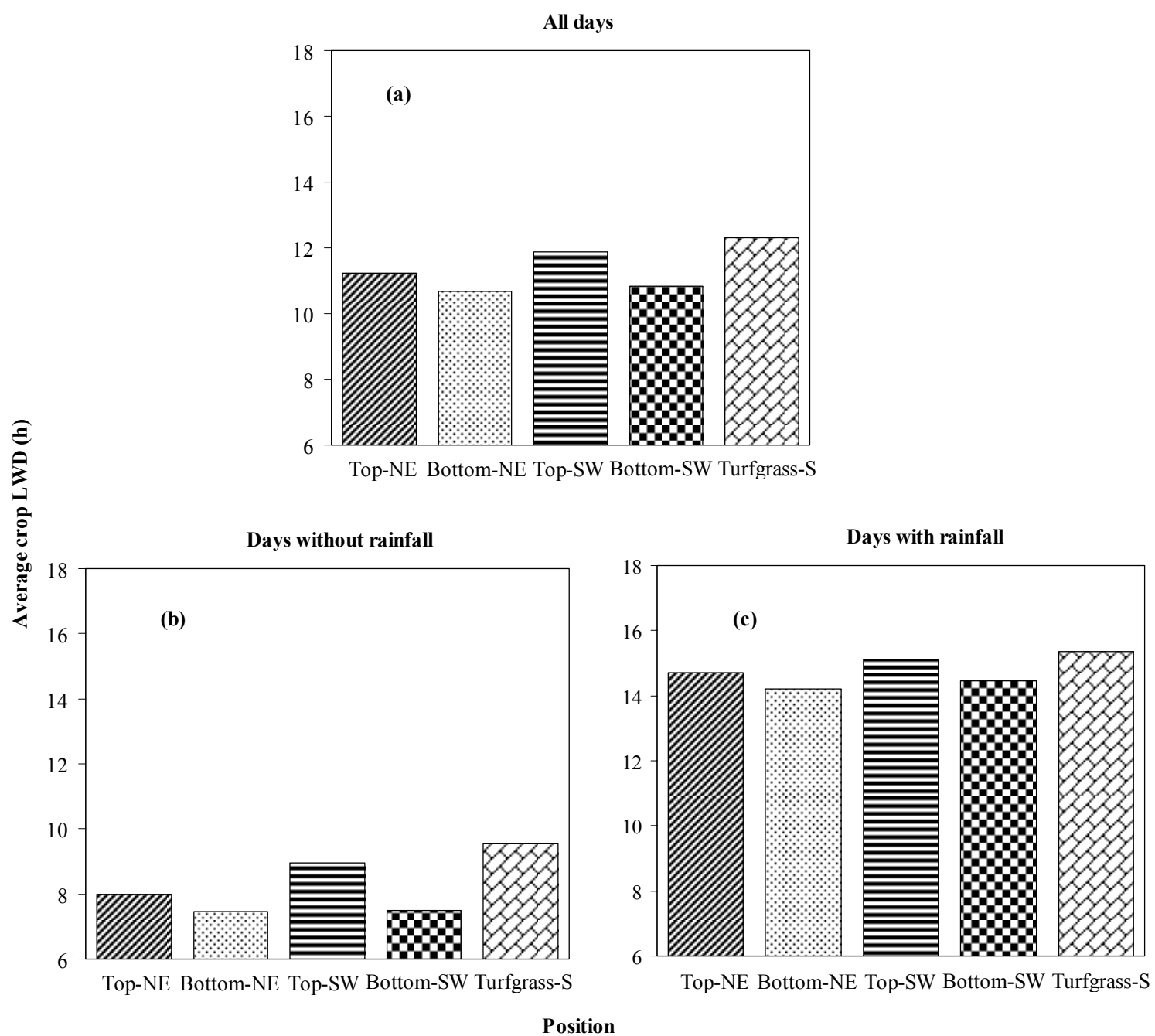

FIGURE 6. Average leaf wetness duration (LWD) at the grapevine canopy (Top-NE, Bottom-NE, Top-SW and Bottom-SW) and at the standard position over turfgrass (Turfgrass-S), considering all days (a) and days without (b) and with rainfall (c). 
LWD at the grapevine canopy was longer at the Top-SW position and shorter at the BottomNE position. These differences were more pronounced in the days without rainfall (Figura 6b). Such fact shows that LWD tended to be longer at the top of the canopy, where the wetness onset occurs earlier, since it is the part of the grapevine canopy more exposed to the sky, with a more negative net radiation than the other positions and also with the leaves facing southwest, which receives less solar radiation in southern hemisphere. At the lowest part of the canopy, less exposed to the sky, LWD tended to be shorter, with the wetness onset occurring later.

LWD measured over turfgrass at standard condition was correlated by simple linear regression with LWD measured at four different positions of the grapevine, for all days and for days without and with rainfall (Figures 7, 8 and 9).

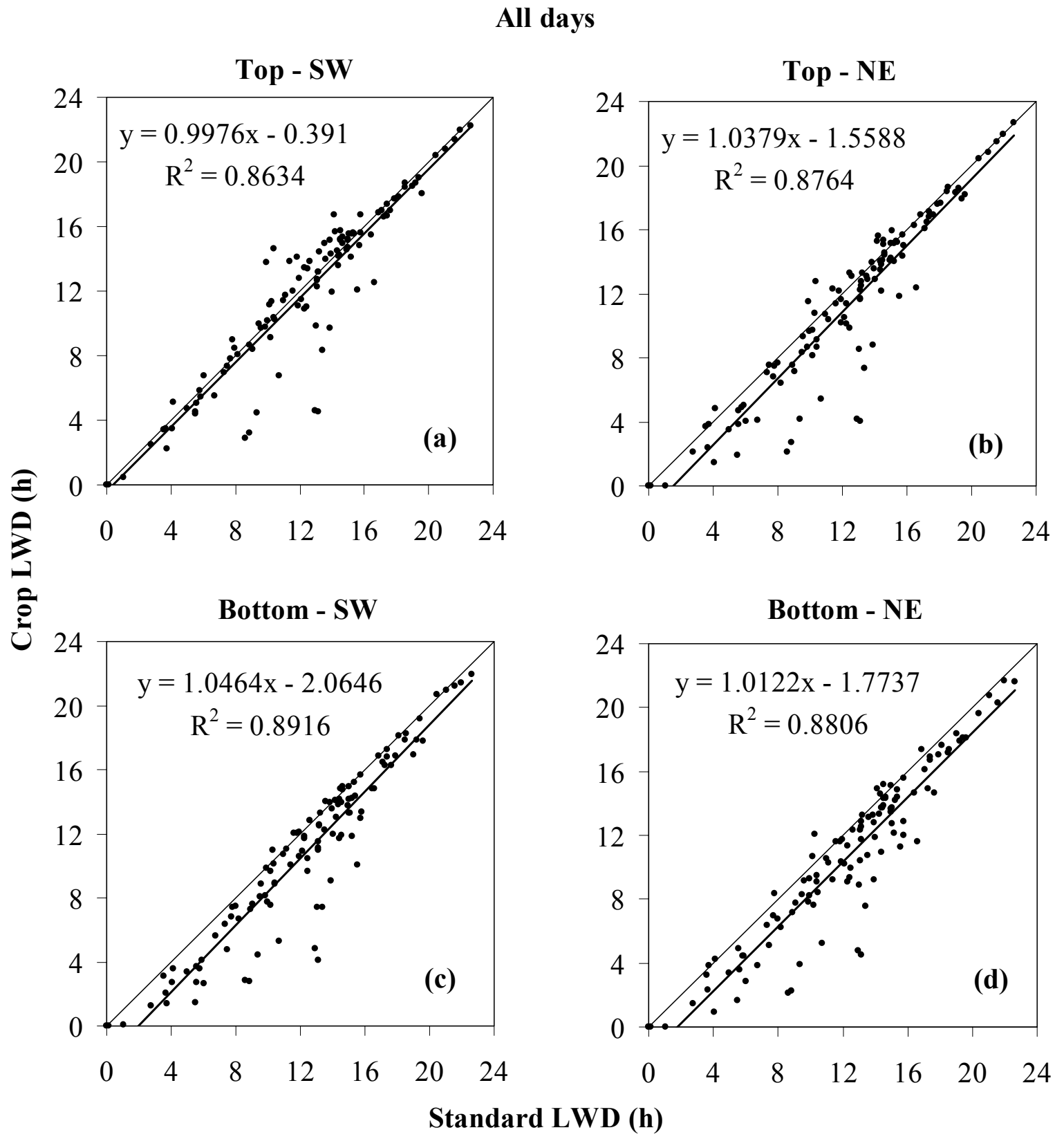

FIGURE 7. Relationship between standard leaf wetness duration (LWD) and crop LWD at different positions of the grapevine canopy: Top-SW (a), Top-NE (b), Bottom-SW (c) and Bottom-NE (d), for all days of the period. 


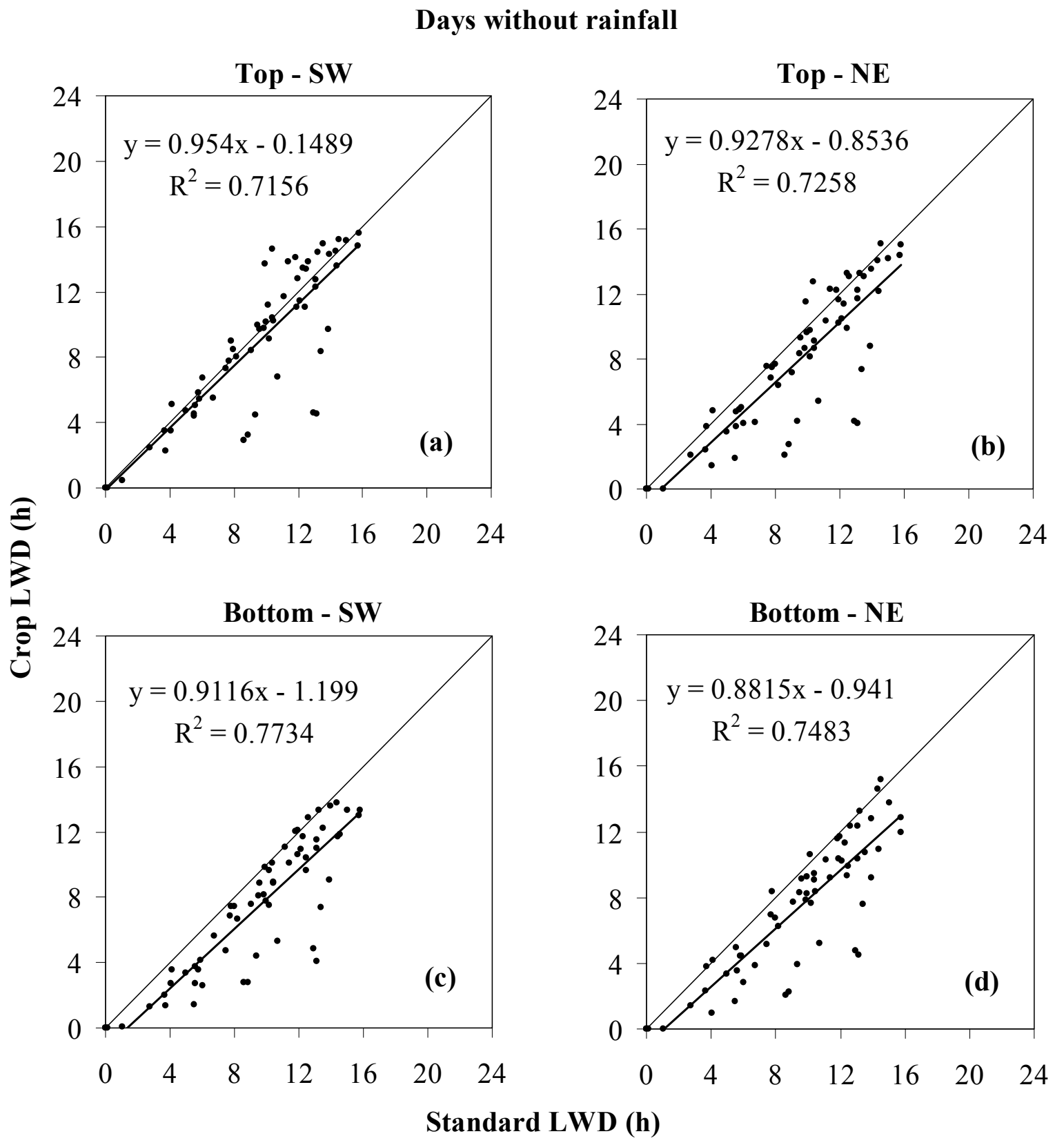

FIGURE 8. Relationship between standard leaf wetness duration (LWD) and crop LWD at different positions of the grapevine canopy: Top-SW (a), Top-NE (b), Bottom-SW (c) and Bottom-NE (d), considering the days without rainfall during the period. 


\section{Days with rainfall}

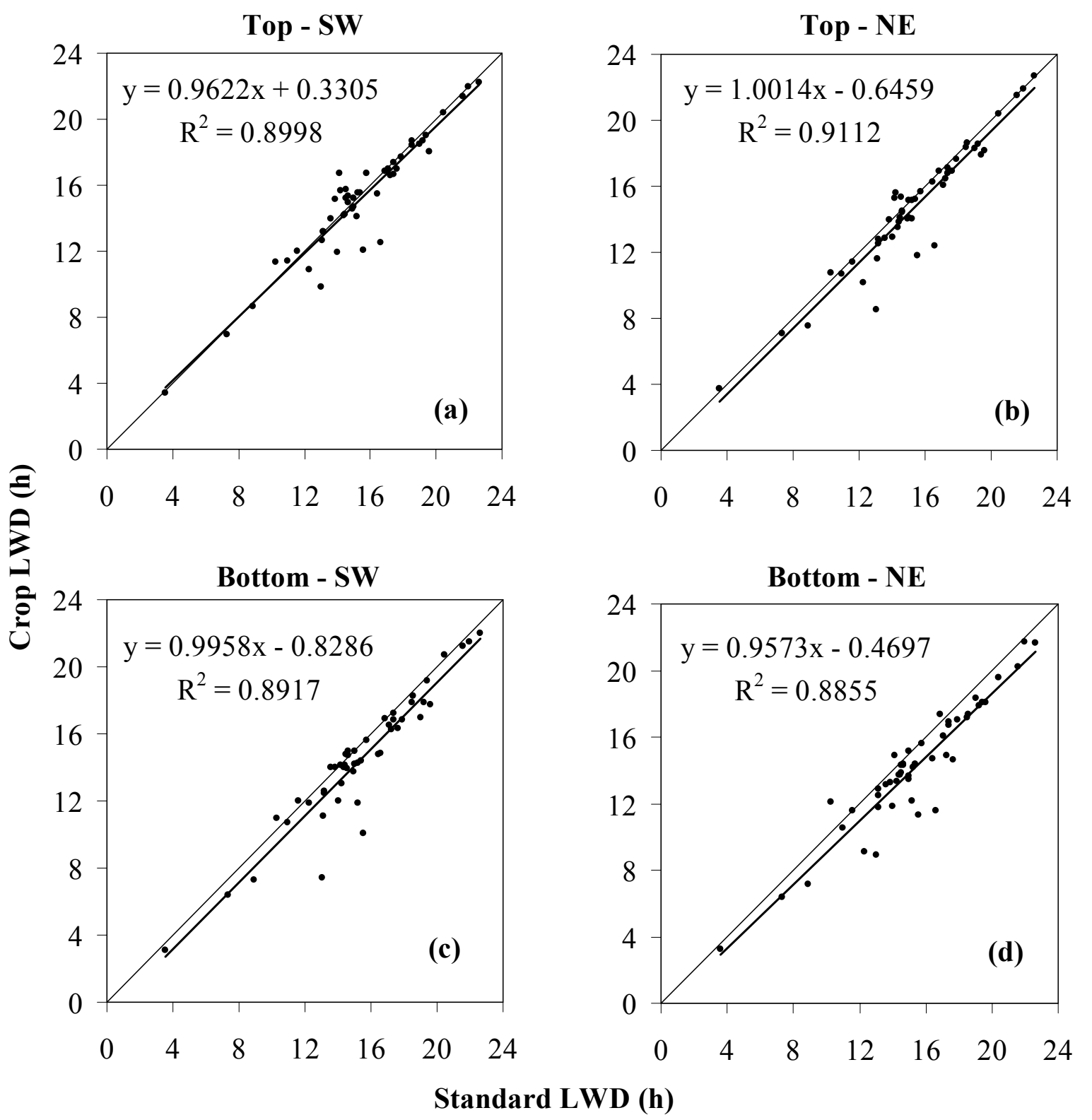

FIGURE 9. Relationship between standard leaf wetness duration (LWD) and crop LWD at different positions of the grapevine canopy: Top-SW (a), Top-NE (b), Bottom-SW (c) and Bottom-NE (d), considering the days with rainfall during the period.

Considering all days from 11 November 2005 to 05 March 2006 (Figure 7), a good relationship were observed between standard LWD over turfgrass and crop LWD at the Top-SW $\left(\mathrm{R}^{2}=0.86\right)$, Top-NE $\left(\mathrm{R}^{2}=0.88\right)$, Bottom-SW $\left(\mathrm{R}^{2}=0.89\right)$ and Bottom-NE $\left(\mathrm{R}^{2}=0.88\right)$ positions of the grapevine.

Considering just days without rainfall (Figure 8), a larger data dispersion was observed, resulting in a worst relationship between standard and crop LWD: Top-SW $\left(\mathrm{R}^{2}=0.71\right)$, Top-NE $\left(\mathrm{R}^{2}=0.72\right)$, Bottom-SW $\left(\mathrm{R}^{2}=0.77\right)$ and Bottom-NE $\left(\mathrm{R}^{2}=0.75\right)$ positions of the grapevine canopy. This happened due to differences between the microclimate over turfgrass and inside the vineyard (different plant structures), affecting the wetness onset and wetness dry-off caused by dew, resulting in a larger spatial variability between standard and crop LWD on days without rainfall.

For the days with rainfall (Figure 9), the best relationships were observed, with the highest determination coefficients: Top-SW $\left(\mathrm{R}^{2}=0.90\right)$, Top-NE $\left(\mathrm{R}^{2}=0.91\right)$, Bottom-SW $\left(\mathrm{R}^{2}=0.89\right)$ and 
Bottom-NE $\left(\mathrm{R}^{2}=0.88\right)$. This smaller data dispersion happened because on days with rainfall the environmental conditions (microclimate) over turfgrass and inside the vineyard become similar, resulting in a small spatial variability between standard and crop LWD.

General analysis of the correlations between LWD measured over turfgrass and at different positions of the grapevine by simple linear regression became possible to affirm that the data dispersion was small, except for days without rainfall, since $\mathrm{R}^{2}$ values were high and significant. Considering the correlation for the complete period (Figure 7), $\mathrm{R}^{2}$ ranged from 0.86 to 0.89 , showing a define correlation between standard LWD over turfgrass and LWD inside the vineyard. Therefore, it is possible to estimate LWD inside the 'Niagara Rosada' vineyard cultivated in a hedgerow training system from LWD measured in standard weather station.

\section{CONCLUSIONS}

Inside the vineyard of 'Niagara Rosada' there was no significant LWD difference between the top of the canopy and bunches height, as well as between the southwest and northeast faces of the crop canopy. Despite have not been observed significant differences of LWD among the different positions of the 'Niagara Rosada' grapevine, the Top-SW presented the longest LWD. This position should be considered as a standard for measurements considering its use in disease warning systems. Leaf wetness duration at the different positions of the grapevine canopy can be estimated from LWD measurements obtained in a standard weather station.

\section{ACKNOWLEDGEMENT}

To FAPESP for the scholarship to the first author and for supporting the present study. To Agronomic Institute (IAC) for the experimental area. To Prof. José Eduardo Macedo Pezzopane (UFES) for the LWD sensors used in the field experiment. To CNPq for the fellowships for the second and third autors.

\section{REFERENCES}

BURRAGE, S.W. Dew on wheat. Agricultural Meteorology, Amsterdam, v.10, p.3-12, 1972.

DALLA MARTA, A.; DE VINCENZI, M.; DIETRICH, S.; ORLANDINI, S. Neural network for the estimation of leaf wetness duration: application to a Plasmopara viticola infection forecasting. Physics and Chemistry of the Earth, Cambridge, v.30, n.1, p.91-6, 2005.

DALLA MARTA, A.; ORLANDINI, S.; GHIRONI, M.; SABATINI, F. Influence of different sensor positions on leaf wetness duration measurements and their effect on the simulation of grapevine downy mildew (Plasmopara viticola). Időjárás: Quarterly Journal of the Hungarian Meteorological Service, Budapest, v.108, n.4, p.253-63, 2004.

GUYOT, J.; OMANDA, E.N.; PINARD, F. Some epidemiological investigations on Colletotrichum leaf disease on rubber tree. Crop Protection, Oxford, v.24, n.1, p.65-77, 2005.

KIM, K.S.; TAYLOR, SE.; GLEASON, M.L.; VILLALOBOS, R.; ARAUZ, L.F. Estimation of leaf wetness duration using empirical models in northwestern Costa Rica. Agricultural and Forest Meteorology, Amsterdam, v.129, n.1, p.53-67, 2005.

MONTEITH, J.L. Dew: facts and fallacies. In: RUTTER, A.J.; WHITEHEAD, F.H. The water relations of plants. Santa Clara: Academic Press, 1961. p.35-56.

PEREIRA, A.R.; ANGELOCCI, L.R.; SENTELHAS, P.C. Agrometeorologia: fundamentos e aplicações práticas. Guaíba: Agropecuária, 2002. 478 p.

RAMAN, C.R.V.; VENKATARAMAN, S.; KRISHNAMURTHY, V. Dew over India and its contribution to winter-crop water balance. Agricultural Meteorology, Amsterdam, v.11, p.17-35, 1973. 
RAO, P.S.; GILLESPIE, T.J.; SCHAAFSMA, A.W. Estimating wetness duration on maize ears from meteorological observations. Canadian Journal of Soil Science, Ottawa, v.78, n. 1, p.149-54, 1998.

SABATINI, F.; DALLA MARTA, A.; ORLANDINI, S.; ZANCHI, C.A. Review of leaf wetness duration sensors. In: DALLA MARTA, A.; KAJFEZ BOGATAI, F.; MARACCHI, G.;

ORLANDINI, S.; ROSSI, F. Leaf wetness duration: analysis of the agrometeorological requirements and evaluation of new estimation methods. Bruxelles: COST 718, European Union, 2004. p.19-28.

SENTELHAS, P.C.; GILLESPIE, T.J.; GLEASON, M.L.; MONTEIRO, J.E.B.A.; HELLAND, S.T. Operational exposure of leaf wetness sensors. Agricultural and Forest Meteorology, Amsterdam, v.126, n.1, p.59-72, 2004.

SENTELHAS, P.C.; GILLESPIE, T.J.; BATZER, J.C.; GLEASON, M.L.; MONTEIRO, J.E.B.A.; PEZZOPANE, J.R.M.; PEDRO JÚNIOR, M.J. Spatial variability of leaf wetness duration in different crop canopies. International Journal of Biometeorology, New York, v.49, n.2, p.363-70, 2005.

SHARMA, M.L. Contribution of dew in the hydrological balance of a semi-arid grassland. Agricultural Meteorology, Amsterdam, v.17, p.321-31, 1976.

VAN DER WAL, A.F. Moisture as a factor in epidemiology and forecasting. In: KOSLOWSKI, T.T. Water deficits and plant growth - Water and plant disease. New York: Academic Press, 1978. p.253-95.

WITTICH, K.P. Some remarks on dew duration on top of an orchard. Agricultural and Forest Meteorology, Amsterdam, v.72, n.1, p.167-80, 1995. 